\title{
Early estimates of recruitment of the Belt Sea cod stock*
}

\author{
RAINER OEBERST and MARTINA BLEIL \\ Bundesforschungsanstalt für Fischerei Hamburg, Institut für Ostseefischerei Rostock, An der Jägerbäk 2, \\ D - 18069 Rostock, Germany.E-mail: rainer.oeberst@ior.bfa-fisch.de, martina.bleil@ior.bfa-fisch.de
}

\begin{abstract}
SUMMARY: The Belt Sea cod stock produced very different year class abundances from 1993 to 1999. After the strong year class 1994 a poor year class 1995 followed. Stronger year classes were observed again in 1996 and in 1997. Comparative analyses of the maturity development of female cods, of the fecundity and of the year class abundance demonstrated the following: The maturity development of female cods from November to March was very different in the years investigated. However, the analyses showed that an early or late beginning of the maturity development did not give any indications concerning the new year class abundance. The year class strength of Belt Sea cod is mainly determined by the portions of female cod having a maturity stage of more than II at the beginning of the main spawning season in March. A trawl survey during the beginning of the spawning season for estimating the portions of active female spawners can be used for assessing the actual potential population fecundity and arriving at a first estimate of the new year class abundance with acceptable accuracy. These data are available before the spawning season of the Belt Sea cod is finished. The large variations of the portions of active female spawners are influenced by the abundance and the spatial distribution of the main prey component age group 1 herring and by the temperature conditions during the prespawning period.
\end{abstract}

Key words: Baltic Sea, cod, year class strength, reproduction, condition, maturity stage

\section{INTRODUCTION}

The importance of recruitment estimation for the prediction of stock abundance is high and extensively described. Early and precise estimations have a special importance for short-term stock predictions. This importance increases when the age structure of the stock is dominated by age groups with a high portion of first spawners.

Such a situation was observed in the Baltic cod stocks during the 1990s. Age groups 3 and 4, corresponding to the length range from $35 \mathrm{~cm}$ to 45 $\mathrm{cm}$, were dominant in the landings of the commer-

\footnotetext{
*Received August 24, 2000. Accepted January 24, 2002.
}

cial fishing in the western Baltic Sea, ICES Subdivision 22 and 24. A comparable situation occurred in the eastern Baltic cod stock, ICES Subdivision 25 to 32 .

The comparisons of the year class abundances of Belt Sea cod (distribution area ICES Subdivision 22 and 24) showed that very different year classes have grown up. Year class 1995 was very poor. In contrast to this the abundances of year classes 1994 and 1996 were high and that of 1997 was very high (ICES, 1999a).

Up to now a first estimate of the new year class of the Belt Sea cod stock come from trawl surveys in November for age group 0 and from surveys in February for assessing age group 1. These data are 
available about one year before the year class is used by commercial fisheries.

Extensive investigations concerning the reproduction biology of Belt Sea cod started in the Institute of Baltic Fisheries, in Rostock in 1992. The analyses concentrated on factors which have effects during the process of ripening of sexual products and during the spawning process. Bleil and Oeberst (1996) showed that high correlation exists between absolute individual fecundity and total body weight for Belt Sea cod, and the fecundity did not vary significantly from one year to the next. Analyses concerning the maturity development of Belt Sea cod (Berner and Vaske, 1981; Bleil and Oeberst, 1997; Müller, 1999) showed that this parameter depends on sex and the total length of the individuals, that this parameter varied considerably between the different years, and that the portions of female cod, which participated in the spawning activities, were very different in the years investigated.

Additional results were obtained in marine hatchery under controlled and almost natural conditions (Bleil and Oeberst, 1998). These experiments confirmed the observations concerning the maturity development in the western Baltic Sea that larger/older cods start their spawning activities earlier and spawn over a longer period than the smaller specimens. Larger individuals are able to develop larger amounts of oocytes until spawning and higher portions of spawned eggs are suitable for fertilisation. These results correspond well with observations of Kjesbu (1994), Kjesbu and Holm (1994, 1996), Marshall et al. (1999), Marteinsdóttir and Steinarsson (1996, 1999) and Trippel (1999).

Furthermore, analyses showed that the factors which determine the recruitment success of the eastern Baltic cod were quite different from those factors which are significant for the Belt Sea stock (Anon., 1998; Oeberst and Oeberst, 1999). During the spawning period in the Belt Sea the hydrographical conditions were in such ranges that fertilisation and development of eggs were not influenced significantly (Bleil and Oeberst, 2000).

Hinrichsen et al. $(1999,2000)$ showed that eggs and larvae of Belt Sea cod can be transported in an eastern direction caused by western winds. Moreover, eastward migrations of juvenile cods were detected in areas east of Bornholm after the settling (Oeberst, 1999).

The aim of this article is to examine the factors that are responsible for the high variations of the year class abundance of the Belt Sea cod stock and

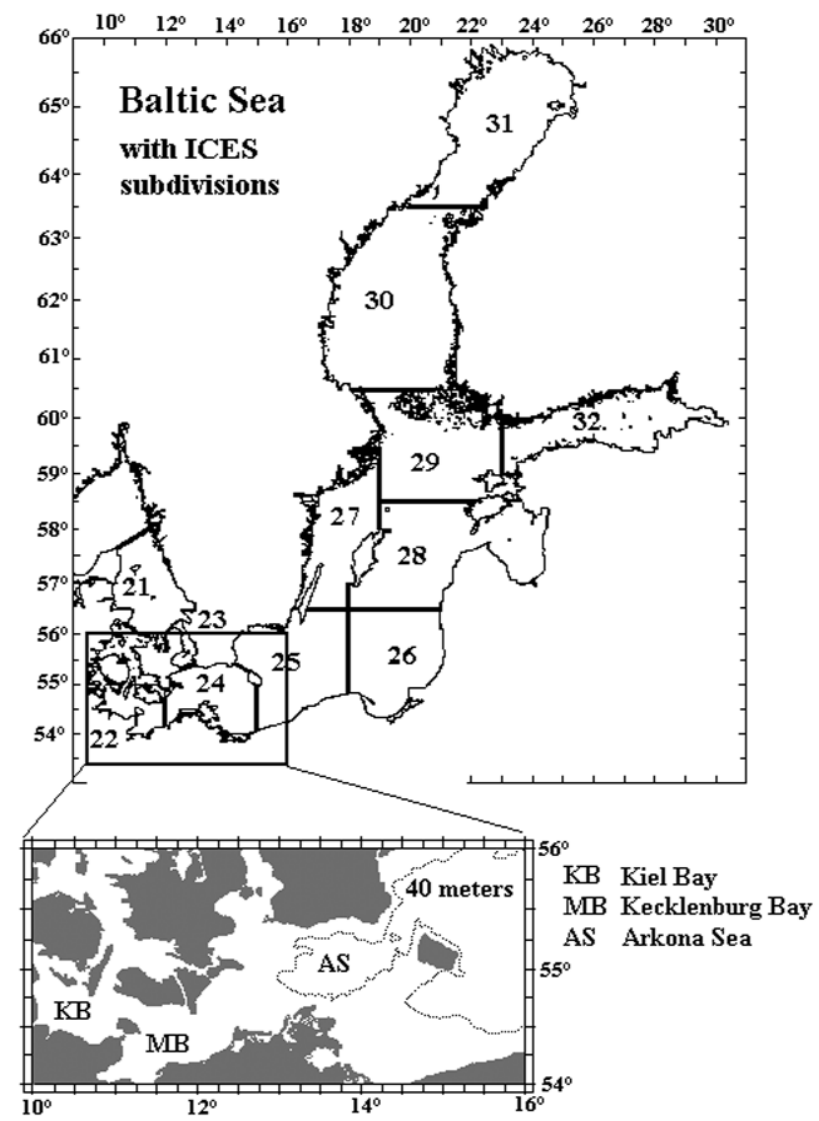

FIG. 1. - Baltic Sea with ICES subdivisions and the area under investigations

to identify those factors that would allow an early prediction of recruitment. The analyses focused on factors which act before and during the spawning process.

\section{MATERIAL AND METHODS}

Figure 1 presents the Baltic Sea with the ICES subdivisions (SD). The area under investigation is shown in a separate map.

The data for estimating the development of ripening and for observing the spawning process (maturity surveys) were sampled with research cutters in November, January and March using a cod end mesh size of $i=105 \mathrm{~mm}$. After each haul hydrographical measurements were carried out using CTD probes. The parameters temperature, salinity and oxygen saturation were sampled as profiles from the surface to near to the bottom. The same stations as used during the demersal trawl surveys in November have been applied during the maturity surveys for sampling data concerning the reproduction biology of cod since 1992 . 
The demersal trawl surveys in November were developed for assessing abundance indices of the cod stocks. The positions of the survey stations were selected randomly based on statistical analyses (Vaske and Schulz, 1980, 1985). After this random selection the positions were used as fixed stations during the subsequent surveys.

Standard routines of the Institute of Baltic Fisheries in Rostock were applied for measuring biological parameters of specimens. All parameters were measured on fresh fish. The following data were used:

- total length,

- total body weight,

- age (using otolith),

- sex and

- maturity stage.

The determination of the maturity stages was carried out macroscopically using the 8-index scale of Maier (1908) modified for cod by Berner (1960).

Since only a low portion of cods caught was aged during the first years of investigation the total length of the specimens was alternatively used. The total length was grouped into $10 \mathrm{~cm}$ length intervals. The length of $35 \mathrm{~cm}$, the minimum landing size for the commercial fisheries, was selected as a starting point. The grouping into $10 \mathrm{~cm}$ classes was applied because the length range from $35 \mathrm{~cm}$ to $45 \mathrm{~cm}$ was dominant in the current cod stock. Since this length range consists mainly of specimens with the age of 3 and 4 years during the spawning seasons of Belt Sea cod (February-May) it is possible to combine length based maturity estimates of this length range with age based stock data of age groups 3 and 4 together.

The results presented are based on analyses of more than 8000 individuals caught in the Belt Sea, Subdivision 22, the most important spawning areas of Belt Sea cod (Bleil and Oeberst, 2000). Additionally, about 800 cods were sampled in the Kattegat (SD 21) and about 6400 specimens were caught in the Arkona Sea (SD24).

The potential population fecundity (the potential egg production) estimates the number of oocytes which are produced by female cods. It is assessed by combining the stock numbers, mean weight-at-age, the maturity ogives and the sex ratios from the assessment working group (ICES, 1999a) together with the absolute individual fecundity. The absolute individual fecundity was estimated by the relation between total body weight and the number of oocytes given by Bleil and Oeberst (1993). They showed that the absolute individual fecundity of
Belt Sea cod was not influenced significantly by area and time.

The assessment working group used constant maturity ogives for the periods from 1990 to 1994 and from 1995 to 1998. Since estimates of the potential population fecundity, which are based on constant maturity ogives, were not suitable for estimating the new year class abundance (Oeberst and Bleil, 1999) and only a low portion of cods caught was aged during the first years of studies, the portions of active female spawners were estimated for length classes in March in year j. $\mathrm{P}_{\mathrm{M} 35}(\mathrm{j})$ denotes the portions of active female spawners of the length range from $35 \mathrm{~cm}$ to $45 \mathrm{~cm}, \mathrm{P}_{\mathrm{M} 45}(\mathrm{j})$ presents estimates of the length range from $45 \mathrm{~cm}$ to $54 \mathrm{~cm}$ and $\mathrm{P}_{\mathrm{M} 55}(\mathrm{j})$ summarizes cods larger than $54 \mathrm{~cm}$. The weighted mean of these values was used to estimate the total portion of active female spawners in March in year $j, P_{M}(j)$, using the length distribution as weighting factor. These estimates in combination with data of stock abundance were applied to estimate the actual population fecundity. An active female spawner was defined as female cods with a maturity stage higher than II with started maturity development. Since the maturity development was only separated into two groups (I-II, III-VIII), the determination of the maturity stage is not likely to be a source of biased estimates.

As an index of the new year class, 0 -group estimates by the German demersal trawl surveys in November were used, $\mathrm{T}_{0}(\mathrm{j})$ (Vaske and Schulz, 1980, 1985; Schulz and Vaske, 1988b; Hinrichs et al., 1991; ICES., 1999b).

To evaluate the temporal process of the maturity development during the prespawning period from November of the previous year until March, the portions of female spawners with a maturity stage higher than II were estimated for November $\left(\mathrm{P}_{\mathrm{N}}(\mathrm{j})\right)$ and January $\left(\mathrm{P}_{\mathrm{J}}(\mathrm{j})\right)$.

In the late eighties an international co-ordinated programme started for analysing the stomach content of cod in the Baltic Sea, for estimating consumption rates of cod and for assessing the preypredator relationships between cod, herring and sprat (Schulz, 1987, 1988, 1989a, b; Bagge, 1989; Uzars, 1989, 1995; Sparholt, 1994). Schulz (1987, 1988, 1989) showed that age group 1 herring is the main food component of cod with a total length larger than $34 \mathrm{~cm}$ in the western Baltic Sea. About 30\% of the prey was herring (about $50 \%$ of the prey was fish). Estimates of abundance and spatial distribution of herring and sprat are available from the inter- 
national coordinated acoustic surveys in the Baltic Sea in October (ICES, 1999b)

Besides the main food component, the strong dynamics of the hydrographical conditions in the deepest areas of the Belt Sea during the prespawning period can influence the maturity development.

To obtain representative mean temperature values in the Belt Sea, data from the Federal Maritime and Hydrography Agency in Hamburg and from the Institute of Baltic Sea Fisheries in Rostock were combined for periods of about two months. These data include continuous measuring of the Kiel Lighthouse $\left(54^{\circ} 30^{\prime} \mathrm{N}, 10^{\circ} 16^{\prime} \mathrm{E}\right)$, of the Fehmarn Belt boy $\left(54^{\circ} 36^{\prime} \mathrm{N}, 11^{\circ} 09^{\prime} \mathrm{E}\right)$ and of the pile Darss Sill $\left(54^{\circ} 42^{\prime} \mathrm{N}, 12^{\circ} 42^{\prime} \mathrm{E}\right)$, as well as measurements of CTD probes.

Using multiple regression models the effects on year class abundance of actual population fecundity, the portions of active female spawners in March, the portions of females which started maturity development in November of the year before, the abundances and the spatial distributions of the main food component of adult cod and the temporal development of temperature close to the bottom of the Kiel Bay and of the Mecklenburg Bay were analysed. The statistical analyses were carried out using the software "Statgraphics Plus" (1996)

\section{RESULTS}

\section{Actual population fecundity, $F_{A}(j)$, and its relation to the year class index, $T_{0}(j)$}

The portions of active spawners in March, $P_{M}(j)$, by length interval and year, including the length intervals from $35 \mathrm{~cm}$ to $44 \mathrm{~cm}, \mathrm{P}_{\mathrm{M} 35}(\mathrm{j})$, from $45 \mathrm{~cm}$ to $54 \mathrm{~cm}, \mathrm{P}_{\mathrm{M} 45}(\mathrm{j})$, and larger than $54 \mathrm{~cm}, \mathrm{P}_{\mathrm{M} 55}(\mathrm{j})$, are presented in Table 1 . The variability of portions of active female spawners was highest for the smallest cods and varied between $18 \%$ and $89 \%$. The portions of larger cods were relatively high and the variability was smaller. However, it should be pointed out that only few cods with a total length of more than $54 \mathrm{~cm}$ were caught.

Using the portions of active female spawners in combination with estimates of stock abundance (ICES, 1999a), the actual population fecundity of the Belt Sea cod stock was estimated. Since the age groups 3 and 4 together made up between $50 \%$ and $86 \%$ of the potential spawning stock, these age groups were dominant in the length range from $35 \mathrm{~cm}$ to $45 \mathrm{~cm}$. Because the por-
TABLE 1. - Portions of the active female spawners (\%) in March by length intervals, $P_{M}(j)$ from 1993 to 1998

\begin{tabular}{lcccc}
\hline \multicolumn{5}{c}{ Length intervals } \\
Year & $35-44 \mathrm{~cm}$ & $45-54 \mathrm{~cm}$ & $\geq 55 \mathrm{~cm}$ & total \\
& $\mathrm{P}_{\mathrm{M} 35}(\mathrm{j})$ & $\mathrm{P}_{\mathrm{M} 45}(\mathrm{j})$ & $\mathrm{P}_{\mathrm{M} 55}(\mathrm{j})$ & $\mathrm{P}_{\mathrm{M}}(\mathrm{j})$ \\
\hline 1993 & 39 & 56 & 67 & 41.4 \\
1994 & 76 & 88 & 95 & 86.4 \\
1995 & 18 & 64 & 89 & 40.8 \\
1996 & 35 & 64 & 53 & 56.7 \\
1997 & 89 & 82 & 97 & 89.3 \\
1998 & 43 & 79 & 96 & 56.7 \\
\hline
\end{tabular}

TABLE 2. - Estimates of the potential and actual population fecundity, $F_{A}(j)$, as well as indices of the year class, $T_{0}(j)$, of the Belt Sea cod stock from 1993 to 1998

\begin{tabular}{cccr}
\hline Year & $\begin{array}{c}\text { Potential population } \\
\text { fecundity in }\left(10^{9}\right)\end{array}$ & $\begin{array}{c}\text { Actual population } \\
\text { fecundity in }\left(10^{9}\right) \\
\mathrm{F}_{\mathrm{A}}(\mathrm{j})\end{array}$ & $\begin{array}{c}\text { Trawl index } \\
\mathrm{T}_{0}(\mathrm{j})\end{array}$ \\
\hline 1993 & 6709 & 9719 & 95.4 \\
1994 & 12359 & 26033 & 681.9 \\
1995 & 17713 & 12494 & 4.8 \\
1996 & 13701 & 18331 & 387.4 \\
1997 & 17766 & 25710 & 3493.1 \\
1998 & 12459 & 15888 & 146.6 \\
\hline
\end{tabular}

tions of active female spawners of this length range $\left(\mathrm{P}_{\mathrm{M} 35}(\mathrm{j})\right)$ varied greatly, it was checked whether the actual population fecundity of these age groups of the Belt Sea cod stock in year $j, F_{A}(j)$, can explain the variability of the year class abundance.

Table 2 shows the estimates of $F_{A}(j)$ together with the potential population fecundity and estimates of the 0-group trawl index, $\mathrm{T}_{0}(\mathrm{j})$. The values of actual and potential population fecundity did not correspond well. It was examined whether a correlation exists between the actual population fecundity, $F_{A}(j)$, and the first estimation of the year class abundance, $\mathrm{T}_{0}(\mathrm{j})$. The regression

$$
\log \left(\mathrm{T}_{0}(\mathrm{j})\right)=-22.7+2.1 * \log \left(\mathrm{F}_{\mathrm{A}}(\mathrm{j})\right)
$$

was estimated. Both regression coefficients were significantly different from zero and the correlation coefficient was 0.88 . The high correlation coefficient of 0.88 shows that the number of oocytes produced by the female cods significantly influences the reproduction success of the Belt Sea cod stock.

\section{Portions of active female spawners in relation to the index of the year class abundance}

Since the combination of data by age group (stock in number, sex ratio...) with the portions of 
active female spawners for length intervals can produce inaccuracies, it was furthermore examined whether the portions of active female spawners with a total length of $35 \mathrm{~cm}$ to $44 \mathrm{~cm}$ in March, $\mathrm{P}_{\mathrm{M} 35}(\mathrm{j})$, were correlated with $\mathrm{T}_{0}(\mathrm{j})$.

The following regression function was estimated with a correlation coefficient of 0.96 :

$$
\log \left(\mathrm{T}_{0}(\mathrm{j})\right)=-9.4+3.8 * \log \left(\mathrm{P}_{\mathrm{M} 35}(\mathrm{j})\right)
$$

The regression coefficients (intercept and slope) were different from zero. The high correlation coefficient is an evidence of the importance of $\mathrm{P}_{\mathrm{M} 35}(\mathrm{j})$ concerning the new year class of the Belt Sea cod stock and that the constant maturity ogives used (ICES, 1999) are not suitable for predicting the new year class abundance.

\section{Possible reasons for the variability of the portion of active female spawner}

Since the portions of active female spawners had such importance concerning the new year class abundance, it was examined which factors determine the variability of the portion of active female spawners in March and whether the year class abundance can be assessed even earlier.

Analyses indicated that the developments of the portions of active female spawners from November

TABLE 3. - Portions of female cod of total length from 35 to $44 \mathrm{~cm}$ in Subdivision 22 with a maturity stage higher than II by month and year

\begin{tabular}{lccc}
\hline Year & $\begin{array}{c}\text { November of the } \\
\text { year before } \mathrm{P}_{\mathrm{N} 35}(\mathrm{j})\end{array}$ & $\begin{array}{c}\text { January } \\
\mathrm{P}_{\mathrm{J} 35}(\mathrm{j})\end{array}$ & $\begin{array}{c}\text { March } \\
\mathrm{P}_{\mathrm{M} 35}(\mathrm{j})\end{array}$ \\
\hline 1993 & 17.0 & - & 38.6 \\
1994 & 0.0 & 33.3 & 76.2 \\
1995 & 14.3 & 6.9 & 17.8 \\
1996 & 32.3 & 38.6 & 34.6 \\
1997 & 24.3 & 72.8 & 89.1 \\
1998 & 0.0 & 10.0 & 42.5 \\
\hline
\end{tabular}

TABLE 4. - Portion of female cod of total length from 45 to $54 \mathrm{~cm}$ in Subdivision 22 with a maturity stage higher than II by month and year

\begin{tabular}{lccc}
\hline Year & $\begin{array}{c}\text { November of the } \\
\text { year before } \mathrm{P}_{\mathrm{N} 45}(\mathrm{j})\end{array}$ & $\begin{array}{c}\text { January } \\
\mathrm{P}_{\mathrm{J} 45}(\mathrm{j})\end{array}$ & $\begin{array}{c}\text { March } \\
\mathrm{P}_{\mathrm{M} 45}(\mathrm{j})\end{array}$ \\
\hline 1993 & 13.3 & - & 55.6 \\
1994 & 23.8 & 46.1 & 87.6 \\
1995 & 15.4 & 37.9 & 64.3 \\
1996 & 76.2 & 65.8 & 63.9 \\
1997 & 28.9 & 54.6 & 82.1 \\
1998 & 4.1 & 55.6 & 79.4 \\
\hline
\end{tabular}

until March were different during the period from 1993 to 1999 . The estimates are given in Tables 3 and 4 . Table 3 presents the estimates for cod with a total length of $35 \mathrm{~cm}$ to $44 \mathrm{~cm}$ for the months November of the year before, January and March. The estimates for cod with a total length of $45 \mathrm{~cm}$ to $54 \mathrm{~cm}$ are given in Table 4 . The portions of active female spawners of spawning season 1996 did not change significantly from November 1995 until March 1996. In contrast to this the portions increased from $0 \%, \mathrm{P}_{\mathrm{N} 35}(\mathrm{j})$, to $76.2 \%, \mathrm{P}_{\mathrm{M} 35}(\mathrm{j})$, and from $23.8 \%, \mathrm{P}_{\mathrm{N} 45}(\mathrm{j})$, to $89.1 \%, \mathrm{P}_{\mathrm{M} 45}(\mathrm{j})$, from November 1993 until March 1994. Similar developments can be observed for other years.

The accumulation of energy reserves, which are necessary for the development of the sexual products, can be influenced by different factors (Hutchings and Myers, 1993; Baranova, 1995; Lambert and Dutil, 1997; Marshall et al., 1998, 1999; Trippel, 1999). Low densities of the main prey organisms can impede the storage of the necessary reserves. Marteinsdóttir et al. (1999) described this effect for cod in Icelandic waters. Furthermore, unfavourable conditions of temperature can influence maturity development.

Therefore, it was analysed whether the increase in the portions of active female spawners during the prespawning period was influenced by the abundance and the spatial distribution of the main food species, age group 1 herring and sprat (Schulz, 1987, 1988, 1989).

Temperature values between $9.5^{\circ} \mathrm{C}$ and $12.9^{\circ} \mathrm{C}$ were observed in the Kiel Bay and in the Mecklenburg Bay in August from 1993 to 1998. Only in August 1997 was a lower temperature of $8.5^{\circ} \mathrm{C}$ measured in the Mecklenburg Bay. In December the temperature varied between $4^{\circ} \mathrm{C}$ and $8^{\circ} \mathrm{C}$. Since these strong changes also can influence the increase in the portions of active female spawners, the temporal development of the mean temperature in the Kiel Bay and in the Mecklenburg Bay was used in the regression models.

Estimates of the abundance of age group 1 herring in October based on international acoustic surveys are presented in Table 5 for the Kiel Bay and the Mecklenburg Bay together (ICES Subdivision 22) and for the Arkona Sea (ICES Subdivision 24) together with mean temperature values of the deepest areas of the Kiel Bay and of the Mecklenburg Bay for the periods October-November, DecemberJanuary and February-March. The values of the mean temperature illustrate the high dynamics of the 
TABLE 5. - Indices of age group 1 herring in different areas estimated by acoustic surveys in October and estimates of mean temperatures close to the bottom in the deepest areas of the Kiel Bay and of the Mecklenburg Bay together by year

\begin{tabular}{|c|c|c|c|c|c|}
\hline \multirow[b]{2}{*}{ Year } & \multicolumn{2}{|l|}{ Acoustic index } & \multicolumn{3}{|c|}{ Mean temperature $\left({ }^{\circ} \mathrm{C}\right)$} \\
\hline & Kiel Bay and Mecklenburg Bay & Arkona Sea & Oct.-Nov. & Dec.-Jan. & Feb.-March \\
\hline 1992 & 507534 & 678005 & 10.4 & 4.8 & 3.1 \\
\hline 1993 & 224900 & 176446 & 10.2 & 4.1 & 1.8 \\
\hline 1994 & 89735 & 242325 & 10.2 & 4.8 & 3.1 \\
\hline 1995 & 418727 & 608528 & 10.7 & 4.9 & 0.7 \\
\hline 1996 & 391779 & 440446 & 9.7 & 5.0 & 3.3 \\
\hline 1997 & 614971 & 672387 & 11.4 & 6.8 & 4.8 \\
\hline 1998 & 257298 & 216546 & 10.0 & 8.3 & 3.1 \\
\hline
\end{tabular}

hydrographical conditions in this area with a water depth of less than $40 \mathrm{~m}$.

Using multiple regression models the importance of the parameters

- index of age group 1 herring in Subdivision $22, \mathrm{H}_{22}(\mathrm{j})$,

- index of age group 1 herring in Subdivision

$24, \mathrm{H}_{24}(\mathrm{j})$,

- index of sprat in Subdivision 22, $\mathrm{S}_{22}(\mathrm{j})$,

- index of sprat in Subdivision 24, $\mathrm{S}_{24}(\mathrm{j})$,

- mean temperature in the deepest areas of the Kiel Bay and of the Mecklenburg Bay during October-November, $\mathrm{TE}_{\mathrm{O}}(\mathrm{j})$,

- during December-January, $\mathrm{TE}_{\mathrm{D}}(\mathrm{j})$, and

- during February-March, $\mathrm{TE}_{\mathrm{F}}(\mathrm{j})$

concerning the development of the portions of active female spawners from November to March, $P_{M 35}(j)-P_{N 35}(j)$, were examined. Since the number of data sets was low it was necessary to consider different models with a more limited number of parameters. The following regression was the model with the highest coefficient of determination (99\%).

$$
\begin{gathered}
\mathrm{P}_{\mathrm{M} 35}(\mathrm{j})-\mathrm{P}_{\mathrm{N} 35}(\mathrm{j})=250.9+0.00041 * \mathrm{H}_{22}(\mathrm{j})- \\
-0.00035 * \mathrm{H}_{24}(\mathrm{j})-19.3 * \mathrm{TE}_{\mathrm{O}}(\mathrm{j})
\end{gathered}
$$

The $p$-value of $\mathrm{TE}_{\mathrm{O}}(\mathrm{j})$ was 0.06 and the $\mathrm{p}$-values of all other independent variables were less than 0.05 . The coefficient of determination and the $p$-values are evidence of the significant influence of the main prey component. Likewise, the p-values suggest that the mean temperature during OctoberNovember was also important. Further models showed that the mean temperature in the subsequent periods were not important for the development of the portions of active female spawners.

Besides the abundance of the main food component, the spatial distribution between the ICES Subdivisions 22 and 24 was also significant. The different sign of the regression coefficients suggests that positive effects can be observed when the main part of this year class stayed in Subdivision 22. Additional analyses showed that the abundance of sprat did not influence the maturity development.

\section{DISCUSSION}

Although the available data base includes only the period from 1993 to 1998 , a relatively short time series for analyses of this type, the results may be representative for the reproduction process of the western Baltic cod because poor, mean and strong year classes occurred during this period. These results are also suitable for developing new and optimised sampling strategies.

The analyses support the hypothesis that the variation of the maturity development significantly influences the year class strength of this stock (Bleil and Oeberst, 1997, 1998). These results correspond with observations concerning the Canadian cod stocks. Trippel (1999) summarised that changes in the age structure of the spawning stock were connected with a "loss of large, old, experienced spawners, younger ages and smaller sizes at sexual maturity, reduced egg quality, shorter spawning period, as well as low condition factors". Such spawning stocks do not produce a stable recruitment and are sensitive to human activities. Since the structure of the spawning stock of Belt Sea cod is dominated by young (age group 3 and 4$)$ and small $(30 \mathrm{~cm}$ to 50 $\mathrm{cm})$ female spawners with high variability of the portions of active female spawners, it is unlikely that a stabilisation of the recruitment will occur in the near future. This hypothesis is supported by the stable relation of the absolute individual fecundity with the total body weight (Bleil and Oeberst, 1996).

The regression functions that describe the relations of the new year class with the actual population fecundity, $F_{A}(j)$, and with the portions of active 
female spawners, $P_{M 35}(j)$, suggest that factors such as oxygen content and predation of eggs by sprat that affect the reproduction success of the eastern Baltic cod stock are not important for the Belt Sea cod stock (Berner et al., 1988a, b, 1989; Plikshs et al., 1993; Nissling et al., 1994; Nissling and Westin, 1997; Wieland, 1995; Anon., 1998; Vallin et al., 1999; Jarre-Teichmann et al., 2000). Less importance of factors that affect the recruitment development after the spawning process is supported by knowledge of the conditions in the area. Although the hydrographical situation in the western Baltic Sea is characterised by a high variability of the essential reproduction parameters salinity, temperature and oxygen content (Nehring et al., 1995, 1996; Matthäus et al., 1994, 1997, 1998, 1999, 2000), Bleil and Oeberst (2000) showed that the hydrographical conditions varied in ranges which did not influence the fertilisation and the development of spawned eggs negatively.

According to Westernhagen (1970), Graumann (1974), Westin and Nissling (1991), Nissling et al. (1994) and Nissling and Westin (1997), salinity is a major factor which influences the fertilisation of cod eggs in the Baltic Sea. Eggs spawned by the Belt Sea cod need a salinity of more than 14 PSU (marine condition). Westernhagen (1970) defined the lowest boundary for successful fertilization with 15 PSU. Investigations of the Institute of Baltic Sea Fisheries in Rostock support these results (Bleil, 1994, 1995, 1999). The salinity close to the bottom and in the reproductive layer varied between 15 PSU and 28.9 PSU in Kiel Bay and in Mecklenburg Bay during the spawning seasons from 1993 to 1998. The temperature varied between $-0.5^{\circ} \mathrm{C}$ and $11.8^{\circ} \mathrm{C}$ in the same period. According to Westernhagen (1970) and Wieland et al. (1994) the range from $2^{\circ} \mathrm{C}$ to $5^{\circ} \mathrm{C}$ is the optimum temperature level for successful fertilization and development of Baltic cod eggs. Laurence and Rogers (1976) showed that temperatures between $0^{\circ} \mathrm{C}$ and $10^{\circ} \mathrm{C}$ also allow successful fertilisation and development of cod eggs. The oxygen contents during the spawning seasons were always higher than $2 \mathrm{ml} / \mathrm{l}$, the limit for successful development of cod eggs in the Baltic Sea (Ohldag, 1991; Wieland et al., 1994).

Hinrichsen et al. $(1999,2000)$ showed that wind determined water transport processes within the upper layer can shift cod eggs from the Belt Sea (SD22) into the Bornholm Basin (SD25) within 25 days. The mostly western winds are the reasons of relative fast decrease in the density of spawned eggs and of larvae per $\mathrm{m}^{2}$ because they are transported into areas where spawning activities do not occur at the same time. As a consequence, the influence by predators decreases. In addition, the competition pressure of hatched larvae at the beginning of active ingestion is smaller than when all larvae stay in the small spawning area. This decrease in density of individuals results also in larger areas for each individual during the settling process. Quantitative estimates of the migration structure of the Belt Sea 0group-cod showed that the main part of these individuals stay in Subdivision 22 and 24 in November (Oeberst, 1999).

The quality of estimates of the year-class abundance of the Belt Sea cod stock, $T_{0}(j)$, of the main prey component age group 1 herring, $\mathrm{H}_{22}(\mathrm{j})$ and $\mathrm{H}_{24}(\mathrm{j})$, and of the portion of active female spawners in March, $\mathrm{P}_{\mathrm{M} 35}(\mathrm{j})$ and $\mathrm{P}_{\mathrm{M} 45}(\mathrm{j})$, are not expected to lead to biased estimates of the analyses. On the one hand Bleil and Oeberst (1997) and Müller (1999) showed that the beginning of March is the most suitable time for estimating the portions of female cod in the Belt Sea that will participate in the spawning activities of the same year. The spawning activities in March did not progress in such a way that the earliest spawners had already finished the spawning process when the samples were taken. Therefore, it is not possible that females, which have the maturity stage II in March, have already spawned all eggs. On the other hand the spawning seasons finish in the late May / early June in this area. Thus, three months remain for maturity development of the female gonads until the maturity stage "spent". This period is too short for female cods with a maturity stage of II to spawn in the current year because the ripening of female gonads takes four months from maturity stage II until maturity stage VI.

The importance of female cods of age groups 3 and 4 and within the length range from $35 \mathrm{~cm}$ to 44 $\mathrm{cm}$ and from $45 \mathrm{~cm}$ to $54 \mathrm{~cm}$ for the recruitment success of the Belt Sea cod follows from the actual composition of the stock. The age groups 3 and 4 , which are dominant in the length range from $35 \mathrm{~cm}$ to $45 \mathrm{~cm}$, form between $52 \%$ and $86 \%$ of the potential spawning stock in number (ICES, 1999a) in the years investigated. These individuals produced between $64 \%$ and $86 \%$ of the potential population fecundity. Hence, strong changes of the portion of active female spawners in these length groups significantly influence the reproductive potential.

$\mathrm{T}_{0}(\mathrm{j})$ is the first VPA independent estimate of the new year class of the western Baltic cod. The time 
interval between estimates of $F_{A}(j)$ and of $T_{0}(j)$ is very short and the influence of predators/cannibalism (Uzars, 1989, 1995) is low in comparison with later estimates of the year-class abundance. The influence of feeding migrations into regions outside the western Baltic Sea is also low (Oeberst, 1999) and the influence of the fisheries regarding age group 0 can be neglected for the period prior to the surveys.

Analyses concerning possible factors that influence the variability of the maturity development of the Belt Sea cod stock suggest that the abundance of age group 1 herring and its spatial distribution in the western Baltic Sea as well as the mean temperature close to the bottom in Kiel Bay and in Mecklenburg Bay during the period from October to November are important.

The negative regression coefficient of the parameter mean temperature suggests that the faster the unfavourable summer temperatures decrease in autumn and winter the more the portions of active female spawners increase from November to March.

Inflow events transport water from the upper layer of the southern Kattegat into the deepest areas of the Belt Sea (Nehring et al., 1995, 1996; Matthäus et al., 1994, 1997, 1998, 1999, 2000). Since the cooling of the warm summer water starts in the surface layer and reaches the deepest water layers only after some months, inflow events speed up the decrease of the water temperature in the deepest regions. Therefore, inflow events improve the conditions for the development of the sexual products.

Kjesbu et al. (1991), Oganesyan (1993), Lambert and Dutil (1997) and Marshall et al. (1998, 1999) showed for cod stocks in the Northwest Atlantic and in the Barents Sea that individuals with low condition, caused by poor feeding conditions, modulate the maturation process by atresia or skipping. Oganesyan (1993) describes for the Barents Sea cod that an essential number of potential spawners did not take part in the spawning. She assumed that a disruption of rhythm of reproduction is related to the insufficient accumulation of exogenous nutritients in the organism. These observations are obviously also true for the Belt Sea cod stock. The variations of age group 1 herring, the main food component for cod (Schulz 1987, 1988a, 1989a, b) influence the maturation process of cod significantly. The different signs of the regression coefficients show that spatial distribution of age group 1 herring is also important.
Summing up all results, a first indication of the new year class abundance of Belt Sea cod is already available before the beginning of spawning activities.

\section{ACKNOWLEDGEMENT}

We thank Hildrun Müller (Institute for Baltic Sea Fishery, Rostock) for helpful comments, and for a critical review of the manuscript.

\section{REFERENCES}

Anon. - 1998. Mechanisms influencing long term trends in reproductive success and recruitment of Baltic cod: Implication for fisheries management (AIR-CT94-1226). Exploitation report.

Bagge, O. - 1989. A review of investigations of the predation of cod in the Baltic. Rapp. P.-v. Reun. Cons. int. Explor. 190: 51-56.

Baranova, T. -1995 . The structure of spawning cod stock in the eastern Baltic during 1972-1995. ICES C.M. 1995 / J:9.

Berner, M. - 1960. Untersuchungen über den Dorschbestand der Bornholm- und Arkonasee 1953 - 1955. Fischerei und Hilfswiss., 9: 31-601.

Berner, M. and B. Vaske. - 1981. Sex ratio and sexual maturity of cod in the Baltic (Sub-divisions $22-25$ ). ICES C.M. 1981 / $J: 16$.

Berner, M., H. Müller and D. Nehring. - 1988a. Zum Einfluss von Umwelt- und Bestandsparametern auf die Rekrutierung des Dorschbestandes der Arkonasee (SD24). - Fisch.-Forsch. Rostock, 26(2): 44-49.

Berner, M., H. Müller and D. Nehring. - 1988b. The influence of environmental and stock parameters on the recruitment of cod Stocks to the east and west of Bornholm, described by regression equations. Rapp. P.- v. Réun. Cons. int. Explor. Mer, 190: 142-146.

Berner, M., H. Müller and D. Nehring, - 1989. The influence of environmental and stock parameters on the recruitment of cod stocks to the east and west of Bornholm, described by regression equations. Rapp. P.-v. Réun. Cons. int. Explor. Mer, 190: 142-146.

Bleil, M. - 1994. Untersuchungen zur Aufzucht von Dorschen (Gadus morhua morhua) der westlichen Ostsee. Teil I : Methodik der Gewinnung und Befruchtung von entwicklungsfähigem Eimaterial. Inf. Fischwirtsch., 41(4): 171-176.

Bleil, M. - 1995. Untersuchungen zur Aufzucht von Dorschen (Gadus morhua morhua) der westlichen Ostsee. Teil II : Aufbau und Hälterung eines Laichfischbestandes sowie Erbrütung der gewonnenen Eizellen. Inf. Fischwirtsch., 42(3): 133-146.

Bleil, M. - 1999. Untersuchungen zur Fortpflanzungsbiologie des Dorsches und zur natürlichen Sterblichkeit seiner Jugendstadien. Projekt Report, supported by the Bundesministerium für Ernährung, Landwirtschaft and Forsten of the Federal Republik of Germany, 86 pp. (unveröff.).

Bleil, M. and R. Oeberst. - 1993. On the accuracy of cod fecundity estimations. ICES C.M. 1993 / D:48, Ref.: J,G

Bleil, M. and R. Oeberst. - 1996. The fecundity of cod in ICES Subdivision 22,24 and 25 in the years 1992 to 1995 (preliminary results). ICES C.M. 1996 / J:08

Bleil, M. and R. Oeberst. - 1997. The timing of the reproduction of cod (Gadus morhua morhua) in the western Baltic and adjacent areas, ICES C.M. 1997 / CC:02.

Bleil, M. and R. Oeberst. - 1998. The spawning of cod (Gadus morhua morhua) under controlled conditions of captivity, quantity and quality of spawned eggs. ICES C.M. 1998 / DD:3.

Bleil, M. and R. Oeberst. - 2000. Reproduction areas of the cod stock in the western Baltic Sea. ICES C.M. 2000 / N:02.

Dickson, R. and K. Brander. - 1993. Effects of a changing windfield on cod stocks of the North Atlantic. Fish. Oceanogr., 2: 124-153. 
Graumann, G. B. - 1974. Investigations on the spawning of Baltic cod in 1968 to 1970. Rapp. P.-v. Réun. Cons. int. Explor. Mer, 166: 7-9.

Hinrichs, R., N. Schulz and B. Vaske. - 1991. Distribution and abundance of cod, herring and sprat in the Western Baltic estimated from Young Fish Surveys. ICES C.M. 1991 / J:26.

Hinrichsen, H.-H., U. Böttcher, R. Oeberst, R. Voss and A Lehmann. - 1999. Drift patterns of cod early life stages in the Baltic: exchange between the western and eastern stock, a physical modelling approach. ICES C.M. 1999 / Y:04.

Hinrichsen, H.-H., U. Böttcher, R. Oeberst, R. Voss and A. Lehmann. - 2001. The potential for advective exchange of the early life stages between the western and eastern Baltic cod (Gadus morhua L.) stocks. Fisheries Oceanography 10(3): 249-258.

Hutchings, J.A. and R.A. Myers. - 1993. Effect of age on the seasonality of maturation and spawning of Atlantic cod, Gadus morhua, in the Northwest Atlantic. Can. J. Fish. Aquat. Sci., 50: $2468-2474$.

ICES. - 1999a. Baltic Fisheries Assessment Working Group. ICES ASC / ACFM:15.

ICES. - 1999b. Baltic International Fish Survey Working Group. ICES ASC / H: 1 .

Jarre-Teichmann, A., Wieland, K., MacKenzie, B., Hinrichsen, H.H., Plihshs, M. and E. Aro. - 2000. Stock-recruitment relationships for cod (Gadus morhua L.) in the central Baltic Sea incorporating environmental variability. Arch. Fisch. Mar. Res., 48(2): 97-123.

Kjesbu, O.S. - 1994. Time of start of spawning in Atlantic cod (Gadus morhua) females in relation to vitellogenic oocyte diameter, temperature, fish length and condition. J. Fish Biol., 45: 719-735.

Kjesbu, O.S., J. Klungsöyr, H. Kryvi, P.R. Witthames and M. Greer Walker. - 1991. Fecundity, atresia, and egg size of captive Atlantic cod (Gadus morhua L.) in relation to proximate body composition. Can. J. Fish. Aquat. Sci., 48: 2333-2343.

Kjesbu, O.S. and J.C. Holm. - 1994. Oocyte recruitment in first time spawning Atlantic cod (Gadus morhua L.) in relation to feeding regime. Can. J. Fish. Aquat. Sci., 51: 1893-1898.

Kjesbu, O.S., P. Solemdal, P. Bratland and M. Fonn. - 1996. Variation in annual egg production in individual captive Atlantic cod (Gadus morhua L.). Can. J. Fish. Aquat. Sci., 53: 610-620.

Laurence G.C. and C.A. Rogers. - 1976. Effects of temperature and salinity on comparative embryo development and mortality of Atlantic cod (Gadus morhua L.) and haddock (Melanogrammus aeglefinus L.) J. Cons. int. Explor. Mer, 36, 3: 220-228.

Lambert, Y. and J.-D. Dutil. - 1997. Can simple condition indices be used to monitor and quantify seasonal changes in the energy reserves of Atlantic cod (Gadus morhua)? Can. J. Fish. Aquat. Sci., 54(1): 104-112.

Maier, H. N. - 1908. Beiträge zur Altersbestimmung der Fische. I Allgemeines. Die Altersbestimmung nach den Otolithen bei Scholle und Kabeljau. Wiss. Meeresuntersuch. Abt. Helgoland, 8, 1908.

Marshall, C.T., O.S. Kjesbu, N.A. Yaragina, P. Solemdal and O. Ulltang. - 1998. Is spawner biomass a sensitiv measure of the reproductive and recruitment potential of Northeast Arctic cod? Can. J. Fish. Aquat. Sci., 55: 1766-1783.

Marshall, C.T., O.S. Kjesbu, A. Zjorsen and P. Solemdal. - 1999. Spawner quality effects on two measures of reproductive potential: have we been counting our eggs before they "ve hatched? ICES C.M. 1999 / Y:07.

Marteinsdóttir, G. and A. Steinarsson. - 1996. Variation in reproductiv characteristics of cod: Effects of females properties on eggs and larvae. ICES C.M. 1996 / G:34.

Martrinsdóttir, G. and H. Björnssson. - 1999. Time and duration of spawning of cod in Icelandic waters. ICES C.M. 1999 / Y:34

Matthäus, W., H.-U. Lass and R. Tiesel. - 1993. The major inflow in January 1993. Cont. Shelf Res., 12: 1375-1400.

Matthäus, W., D. Nehring and G. Nausch. - 1994. Effects of the Inflows of Salt-rich Water during 1993 and early 1994 in the central Baltic Sea. ICES C.M. 1994 / Q:3.

Matthäus, W. and H.-U. Lass. - 1996. The recent salt inflow into the Baltic Sea. J. Phys. Oceanogr., 25: 280-286.

Matthäus, W., D. Nehring, H.-U. Lass, G. Nausch, K. Nagel and H. Siegel. - 1997. Hydrographisch-chemischen Zustandseinschätzung der Ostsee 1996. Meereswiss. Ber., Warnemünde, 24: $1-49$.
Matthäus, W., G. Nausch, H.-U. Lass, K. Nagel and H. Siegel. 1998. Hydrographisch-chemischen Zustandseinschätzung der Ostsee 1997. Meereswiss. Ber. Warnemünde, 29: 1-65.

Matthäus, W., G. Nausch, H.-U. Lass, K. Nagel and H. Siegel. 1999. Hydrographisch-chemischen Zustandseinschätzung der Ostsee 1998. Meereswiss. Ber., Warnemünde, 35: 1-68.

Matthäus, W., G. Nausch, H.-U. Lass, K. Nagel and H. Siegel. 2000. Hydrographisch-chemische Zustandseinschätzung der Ostsee 1999. Institut für Ostseeforschung Warnemünde, 1-73.

Müller, H. - 1999. The appropriate date of sampling for estimating the proportion of spawners at age. Working paper to the Baltic Fisheries Assessment Working Group Meeting, April 1999.

Nehring, D., W. Matthäus, H.-U. Lass, G. Nausch and K. Nagel. 1995: Hydrographisch-chemischen Zustandseinschätzung der Ostsee 1994. Meereswiss. Ber., Warnemünde, 9: 1-71

Nehring, D., W. Matthäus, H.-U. Lass, G. Nausch and K. Nagel. 1996. Hydrographisch-chemischen Zustandseinschätzung der Ostsee 1995. Meereswiss. Ber., Warnemünde, 16: 1-43.

Nissling. A., H. Kryvi and L. Vallin. - 1994. Variations in egg byoancy of Baltic cod Gadus morhua and its implications for egg survival in prevailing conditions in the Baltic Sea. Mar. Ecol. Prog. Ser., 110: 67-74.

Nissling. A. and L. Westin. - 1997. Salinity requirements for successful spawning of Baltic and Beltsea cod and the potential for cod stock interactions in the Baltic Sea. Mar. Ecol. Prog. Ser., 152: 261-271.

Oeberst, R. - 1999. Exchanges between the western and eastern Baltic cod stocks using the length distributions of trawl surveys. ICES C.M. 1999 / Y:08.

Oeberst, R. and M. Bleil. - 1999. Relations between the year class strength of the western Baltic cod and inflow events in the autumn. ICES C.M. 1999 / Y:32.

Oganesyan, S.A. - 1993. Periodicity of the Barents Sea cod reproduction. ICES C.M. 1993 / G:64.

Ohldag, S. - 1991. Der Einfluß von Sauerstoffmangel auf die Entwicklung von Dorscheiern. Diplomarbeit, Kiel.

Plikshs M., M. Kalejs and G. Grauman. - 1993. The influence of environmental condition and spawning stock size on the year class strength of the eastern Baltic cod. ICES C.M. 1993 / J:22.

Schulz, N. - 1987. First results of cod stomach investigations in the western Baltic (ICES-subdivision 22 and 24) since 1978. ICES C.M. $1987 / J: 25$

Schulz, N. - 1988. Erste Ergebnisse der Nahrungsuntersuchungen zum Dorsch (Gadus morhua L.) der westlichen Ostsee unter besonderer Berücksichtigung seines Einflusses auf die Heringsund Sprottbestände in diesem Seegebiet. Fischerei-Forschung, 26(2): 29-36

Schulz, N. - 1989a. Untersuchungen zur täglichen Nahrungsaufnahme (Tagesration) des Dorsches der westlichen Ostsee. Fischerei-Forschung., 27(2): 37-44.

Schulz, N. $-1989 \mathrm{~b}$. An analysis of the food intake of cod as basis for multispecies assessments in the western Baltic. Rapp. P.-v. Reun. Cons. int. Explor. 190: 67-71.

Schulz, N. and B. Vaske. - 1988. Methodik, Ergebnisse und statistische Bewertung der Grundtrawlsurveys in der Mecklenburger Bucht, Arkonasee und des nördlichen Bornholmbeckens in den Jahren 1978-1985 sowie einige Bemerkungen zu den Jahrgangsstärken des Dorsches (Gadus morhua) und des Herings (Clupea harengus L.). Fischerei-Forschung, 26(3): 53-67.

Sparholt, H. - 1994. Fish species interactions in the Baltic Sea. Dana, 10: 131-162.

Statgraphics Plus. - 1996. Manugistics, Inc

Trippel, E. - 1999. Estimation of stock reproductive potential: History and challenges for Canadian Atlantic gadoid stock assessments. J. Northw. Atl. Fish. Sci., 25: 61-81.

Uzars, D. - 1989. Feeding of Baltic cod (Gadus morhua callarias L.) and its role in the sea ecosystem. Rapp. P.-v. Reun. Cons. int. Explor., 190: 63-66.

Uzars, D. - 1995. Cannibalism of cod in the Gotland Basin of the Baltic Sea. ICES C.M. $1995 / J \cdot 13$.

Vallin, L., A. Nissling and L. Westin. - 1999. Maternal effects on egg size in cod, Gadus morhua, with implications for reproductive success in the Baltic Sea. Nordic Res. Coop. on Reprod. Disturb. in Fish; Report Redfish Project 530; 129-141.

Vaske, B. and N. Schulz. - 1980. Application of some statistical methods to results of groundfish surveys in the Mecklenburg Bay and in the Arkona Basin in November 1978 and 1979. ICES C.M. 1980 / J:20. 
Vaske, B. and N. Schulz. - 1985. Results of GDR-youngfish surveys in the Baltic and some investigations on the precision of year class abundance indices. ICES C.M. 1985 / J:10.

Westernhagen, H. v. - 1970. Erbrütung der Eier von Dorsch (Gadus morhua), Flunder (Pleuronectes flesus) und Scholle (Pleuronectes platessa) unter kombinierten Temperatur und Salzgehaltsbedingungen. Helgoländer wiss. Meeresunters. 21: 21-102.

Westin, L. and A. Nissling. - 1991. Effects of salinity on spermatozoa motility, percentage of fertilized eggs and egg development of Baltic cod (Gadus morhua), and implications for cod stock fluctuations in the Baltic. Mar. Biol.. 108(1): 5-9.

Wieland, K., U. Waller and D. Schnack. - 1994. Development of Baltic cod eggs at different levels of temperature and oxygen content. Dana, 10: 163-177.

Wieland, K. - 1995. Einfluß der Hydrographie auf die Vertikalverteilung und Sterblichkeit der Eier des Ostseedorsches (Gadus morhua callarias) im Bornholmbecken, südliche zentrale Ostsee. Dissertation, Berichte aus dem IFM Kiel, Nr. 266. 